\title{
Analysis of Elementary School Teachers' Work Discipline at UPTD Education in Banyumanik, Semarang City
}

\author{
Muhamad Afandi ${ }^{1, *}$, Zulela $\mathrm{MS}^{2}$, and Amos Neolaka ${ }^{3}$ \\ ${ }^{1}$ Elementary Teacher Education, Sultan Agung Islamic University, Indonesia \\ ${ }^{2}$ Department of Elementary Education. State University of Jakarta, Indonesia \\ ${ }^{3}$ Department of Elementary Education. State University of Jakarta, Indonesia
}

\begin{abstract}
This study is aimed to describe the elementary school teachers' work discipline at the UPTD Education in Banyumanik, Semarang City. The study involved 162 elementary school teachers. The instrument used in this study was a questionnaire consisting of 30 statement items, and 5 indicators of work discipline for elementary school teachers. The findings showed that each indicator of discipline of time was very good (90.8), discipline of work was good (90.1), discipline in work atmosphere was very good (91.4), discipline in serving community was good $(88,9)$, discipline of attitude and behavior was sufficient (75). Overall, the work discipline of elementary school teachers was good (87). These findings indicated that the elementary school teachers at the UPTD education in Banyumanik, Semarang City worked in welldiscipline.
\end{abstract}

Keywords: work discipline, teacher and elementary school

\section{Introduction}

Education, as stated in Act Number 20 of 2003 concerning National Education System, is a process carried out consciously and planned to actualize fun learning atmosphere and learning processes so that students become very active and develop their potentials in order to increase their knowledge, insight and experience to determine their life goals, by which they can eventually gain broader insight for a better future.

The purpose of national education as explained in Article 3 is to develop students' potentials in order to become faithful and fearful humanbeings to God Almighty, noble, healthy, knowledgeable, capable, creative, independent, disciplined, responsible and democratic citizens. (Act Number 20 of 2003, 2012). Education is a process in which practice involves various aspects to support students' success and to develop their existing potentials, either cognitive, affective or psychomotor aspects. Education is also a basic need in human life because humanbeing education will always count on knowledge, attitudes, and habits which are in accordance with existing norms (Afandi \& Yustiana, 2018).

Education of discipline character is an important thing to consider in order to foster a person's character. Armed with the value of discipline character will encourage the growth of other good character values, such as responsibility, honesty, cooperation, and so on (Wuryandani, Maftuh, \& Budimansyah, 2014). Undisciplinary behavior is also often found in school environments, including elementary schools. Some examples of such undisciplined behavior are including; late coming to school, wearing incomplete uniform in accordance with what's stated in the school rules, sitting or walking comfortably on grass with clear written notification "prohibited to steping on the grass", littering, scribbling on the walls of schools, skipping school, submitting tasks late, not putting uniforms on according to the rules, and so on.

Discipline stated in (Government Regulation, 2010) concerning the Discipline of Civil Servants is explained that discipline is the ability of Civil Servants to comply with obligations and avoid prohibitions specified in the legislation and/or official regulations with respect to giving penalty to those who violate and disobeyed. In addition, various rules established by a school or educational institution have a very important role in creating discipline so that teachers can comply with and implement the rules. The rules or norms are usually followed by sanctions given when they are found violating. The sanctions can be in the form of both oral and written reprimands, suspension, degrading position,

Corresponding author: mafandi@unissula.ac.id 
and even job dismissal. It depends on the amount of violations committed by a teacher.

This is in line with the explanation (Wuryandani et al., 2014) that educator's moral and character have a major role in students' moral development through a hidden curriculum manifested in interpersonal environment of schools and classrooms. In classroom, teachers need to do various things to support the success of the discipline character education program, among which are having a very close and warm relationship with students, turning classroom into a laboratory discipline for students, controlling the students' behavior, and provide time to address the issue of behavior which is not in accordance with the rules that should be.

It is intended that teachers work in discipline and become responsible for their work. If thier work discipline is very high, it is expected that they can complete assignments quickly and precisely so that job satisfaction arises (Mulyasa, 2013).

Thus, it is clear that the teacher's work discipline is the main factor which determines the success of learning quality in elementary schools. Thus in this article describes discipline of elementary school teachers'are adjusted to schedule, therefore, this study is aimed at describing the elementary school at the UPTD education, Banyumanik, Semarang City.

\section{Research Method}

The research method used was quantitative descriptive. The research site was carried out in all state elementary schools at UPTD Education Bayumanik, Semarang City, Central Java, as many as 31 schools. Population is a generalization area consisting of objects with certain quantity and characteristics determined by researchers to be studied and then drawn to conclusions (Sugiyono, 2016) .

The population in this study were State Elementary School teachers at UPTD Education Banyumanik, Semarang City, with a total of 7 Teacher Working Groups, and the overall class teachers were 272 community. In this study, the sampling technique was done by using simple random sampling of area with sampling respondent determination in lottery. The samples gained in this study were 162 teachers. The sampling technique was conducted by random method of each UPTD Education Group in Banyumanik, Semarang City. The determination of the teachers was drawn based on the Teacher Working Group, then the teachers in each school were randomly sampled with the reason that each school and teacher of each school had the same opportunity as a sample.

The data collection of this study was conducted using questionnaire. Questionnaire is a technique or method of collecting data indirectly (the researcher did not directly ask the respondents). The questionnaire instrument contained a number of questions or statements that must be answered or responded by the respondents (Sumadinata, 2013)

To capture information or data from the respondents, the research instruments are prepared. The questionnaire instrumets were made based on conceptuality, including conceptual definition, operational definition, and research instrument guideliness, instrument calibration, Validity and Realiability Testing. The number of statements has four alternative answers. The measurement scales of the questionnaire instruments were made based on Likert scale with four alternative answers, namely: (1) Always with a score of 4 , (2) Often with a score of $3,(3)$ Sometimes with a score of 2 , (4) Never with a score of 1.

The research data were collected, analyzed descriptively with the criteria in accordance with the regulation of minister of Utilization of State Apparatus and Bureaucratic Reform 2009 article 15 as follows; a. values of 91 to 100 are called very good; b. values of 76 to 90 are called good; c. values of 61 to 75 are sufficient; d. values of 51 to 60 are called medium; and e. values up to 50 are called less.

\section{Findings And Discussion}

\subsection{Findings}

The findings of this study focus on those related to the work discipline of elementary school teachers, which was composed of discipline of time, discipline of work, discipline in working atmosphere, discipline in serving community, discipline of attitude and behavior.

Based on the data analysis, it was found that the average score was 87 for work discipline with 'good' criteria. In addition, based on the number of teachers participating in this study, there was discipline criteria of teacher work from 162 teachers, 60 teachers were identified (37.04\%) with 'very good' work discipline criteria, there were 85 teachers $(52.47 \%)$ on the criteria of 'good', there were 16 teachers $(9.88 \%)$ on the criteria of 'sufficient', and there was 1 teacher $(0.62 \%)$ on the criteria of 'medium'.

Meanwhile, the achievement of the indicators of elementary school teachers' work discipline, which was composed of time discipline, work discipline, working atmosphere discipline, discipline in serving community, discipline in attitude and behavior at the UPTD education Banyumanik are presented in Table 1

Table 1. Data of Work Discipline Result of Elementary School Teachers.

\begin{tabular}{|l|l|l|l|}
\hline No & \multicolumn{1}{|c|}{ Indicators } & \multicolumn{1}{|c|}{ Score } & Criteria \\
\hline 1 & Discipline in time & 90.8 & Very Good \\
\hline 2 & Discipline in work & 90.1 & Good \\
\hline 3 & $\begin{array}{l}\text { Discipline inwork } \\
\text { atmosphere }\end{array}$ & 91.4 & Very Good \\
\hline 4 & $\begin{array}{l}\text { Discipline in serving } \\
\text { community }\end{array}$ & 88.9 & Good \\
\hline
\end{tabular}




\begin{tabular}{|c|l|l|l|}
\hline 5 & $\begin{array}{l}\text { Discipline in attitude and } \\
\text { behavior }\end{array}$ & 75 & Sufficient \\
\hline Average & $\mathbf{8 7}$ & Good \\
\hline
\end{tabular}

The data showed that the score of elementary school teachers' work discipline on each indicator as follows; the discipline in time was 90.8 , the discipline in work was 90.1 , the discipline in work atmosphere was 91.4, the discipline in serving the community was 88.9 , the discipline in attitude and behavior was 75 . The average score of the five indicators was 87 and classified as 'good'.

The indicator of discipline in time of the elementary school teachers was classified as "very good". This shows that the teacher had already had discipline in time, both obeying task time, using time well, and completing the task on time.

The Indicator of discipline in teachers' work was classified as 'good', showing that teachers owned discipline in work based on three item statements, namely complying with work rules, preparing teaching equipments, and performing basic tasks.

The implementation of discipline in teaching atmosphere was at the criteria of 'good' based on sub- indicator, namely utilization of work environment, good relationships and maintaining rights and obligations so as to balance.

The implementation of discipline in serving community was in 'good' criteria. The highest criterion was in the statement item of serving students with very good criteria. Whereas, in the criteria, both seen from discipline in serving community were the teacher's discipline in serving students, parents and the surrounding community.

The indicator of discipline of elementary school teachers' attitude and behavior was in the criteria of 'good'. In this case, for the statement concerning behavior, it needs to be improved because it is in sufficient criteria, while the highest criteria are in the statement item, paying attention to attitudes and selfesteem, which were with good criteria.

\subsection{Discussion}

The findings indicate that the work discipline of Banyumanik Elementary School Teachers in Semarang City was at the criteria of 'good' as proven by the results of the instrument on teacher work discipline, which consists of five indicators, namely discipline of time, discipline of work, discipline of work atmosphere, discipline in serving community, discipline of attitudes and behavior.

First, in the discipline of time, teachers were asked dealing with time, either to obey tasks, to manage time well and to complete the tasks on time, the findings showed that the elementary school teachers' discipline was very good. As confirmed by (Danim, 2015) that self-discipline (self-discipline) as the ability to position yourself to take action regardless of the emotional atmosphere. In other words, self-discipline is a selfcontrol and a self-consistency. For a teacher, teacher discipline is the ability of the teacher to position himself to take certain actions in accordance with substance, procedure, time limit, and criteria for them goals to achieve.

Second, the discipline of teachers' work, whether obeying work rules, preparing teaching, equipments, and carrying out the main tasks, the findings of the study indicate that the elementary school teachers had the discipline of work with the criteria of 'good'. (Aqib, 2012) asserts that discipline is an action displaying orderly behavior and complying with various rules and regulations. In line with Aqib, stating that work discipline is an attitude, behavior, and action that is in accordance with rules both written and unwritten, and if violating, there will be sanctions for the violations. (Susanty \& Baskoro, 2012) In line with (Rahman, 2014) state that implementing discipline is an important activity which needs to be done to improve the discipline of teachers at school, because the core of the coaching discipline is discipline itself firmly especially in providing sanctions to those who violate the discipline. The provision of sanctions is intended to raise awareness so as not to violate work discipline, such as a delay between when a goal is formulated and when that goal is achieved.

Third, the discipline of the teachers' atmosphere by utilizing the work environment, establishing good relationships and maintaining a balance between rights and obligations, the findings of the study showed that the elementary school teachers were in the criteria of 'good'. (Stanley, 2014) emphasizes that discipline and academic performance is the key to success in the field of education and both are strategies used to instill positive behavior and character of students, self-control and regulatory compliance at school. The same thing was conveyed by (Arianto, 2013) that the indicators of the work culture of the teaching staff are as follows: (1) the physical environmental conditions of work, including: awarding, providing welfare, fulfilling infrastructure and facilities. (2) work environment conditions, including: support in carrying out tasks, being able to design work, supervision and work discipline, communication and interaction with peers, parents of students, principals and community environment, principal's leadership functions, establishing individual policies, school programs in accordance with the nature and objectives, setting compensation policies and school management.

Fourth, the implementation of discipline in serving community with sub-indicators of serving students, parents and the surrounding communities, the findings showed that the elementary school teachers had 
discipline in serving the community with 'good' criteria. (Niesche, 2010) reveals that community or environment discipline is a period of social control where power is no longer used to punish individuals who violate, but to improve their potential. To achieve this, there needs to be a mechanism that can function corrective as an evaluation of various elements of society.

Fifth, the discipline of attitudes and behavior with subindicators, such as paying attention to attitudes, behavior and self-esteem, the findings of the study showed that the elementary school teachers had the discipline of attitudes and behavior with 'good' criteria. Affirmed by (Walters \& Frei, 2007), dicipline is related to how someone behaves, namely management and self-control. Therefore, classroom management is the teachers' responsibility. In line with (Susanty \& Baskoro, 2012), work discipline is an attitude, behavior and deed based on rules both written and unwritten, and if there is a violation, there will be sanctions for the violation.

The teachers'work discipline consisted of these five indicators, namely discpline of time, discipline of work, discipline of work atmosphere, discipline in serving community, discipline of attitudes and behavior, must be owned by teachers in order to guarantee the quality of the implementation of learning process in elementary school.

In this study, work discipline refers to attitude of obedience, loyalty and awareness of elementary school teachers toward applicable regulations in the form of behavior and actions in an organization to achieve a certain goal. The indicators to measure work discipline, such as discipline of time, discipline of work, discipine in work atmosphere, discipline in serving community, and discipline of attitudes and behavior.

As confirmed in the opinion of (Shih, Wu, Lai, \& Liao, 2015) that lately, positive discipline attitude is the main thing in school and every educator must have this attitude so that it can improve the quality of learning and have a direct impact on the students' attitudes and discipline. Similar opinions expressed by (Rahimi \& Karkami, 2015), stating that teacher discipline strategies can have a positive impact on the students' learning and protect them from cognitive and emotional threats. In this case, it can be hypothesized that when teachers are disciplined, involviong students in decision-making and recognizing each student's character, students will be more responsible in the classroom.

Based on this statement, it can be said that the role of discipline is absolutely necessary in the world of education. Lack of teachers' discipline can decrease the quality of learning in the classroom as well as trigger negative actions of students, such as disobedient to school rules, late, violence, drug abuse and so on.

Most of the discipline behavior in everyday classroom activities is not clearly written in the learning implementation plan made by the teacher. Most are in the form of hidden curricula which are manifested in teachers' daily behavior. The teachers' discipline in entering classroom, wearing uniforms, managing the class is all considered by students.

\section{Conclusion}

The description of the implementation of work discipline of the elementary school teachers at UPTD education in Banyumanik, Semarang city is in 'good' criteria. This is indicated with an average score of 87 . Furthermore, the acquisition of each indicator as follows: discipline of time is very good $(90,8)$, discipline of work is good (90.1), discipline in work atmosphere is very good (91.4), discipline in serving community is good (88.9), discipline of attitude and behavior is enough (75)

\section{Acknowledgement}

The researcher delivers his gratitudes to the Directorate of Research and Community Service, Directorate General of Research and Development, Ministry of Research, Technology and Higher Education of the Republic of Indonesia who have provided Doctoral dissertation grant to complete research and doctoral program studies. This article is part of dissertation research to complete the Doctor in Elementary Education at Postgraduate Program of University of Jakarta.

\section{References}

1. Aqib, Z. (2012) Pendidikan karakter di Sekolah. Bandung: Yama Widya

2. Afandi, M., \& Yustiana, S. (2018). The Performance of Primary School Teachers In the Unit of Education Technical Implementation, 1(2), 81-91. Retrieved from https://ejournal.unri.ac.id/index.php/JTLEE/article/v iew $/ 5878$

3. Arianto, D. A. N. (2013). Pengaruh Kedisiplinan, Lingkungan Kerja Dan Budaya Kerja Terhadap Kinerja Tenaga Pengajar. Jurnal Economia, 9(2), $191-200$

4. Mulyasa. (2013). Pengembangan dan Implementasi Kurikulum 2013. Bandung: Rosda Karya.

5. Niesche, R. (2010). Discipline through documentation: A form of governmentality for school principals. International Journal of Leadership in Education, 13(3), 249-263. https://doi.org/10.1080/13603121003692967

6. Peraturan Pemerintah, R. I. Peraturan Pemerintah R.I Nomor 53 Tahun 2010 Tentang Disiplin Pegawai Negeri Sipil, Pub. L. Nomor 53 Tahun 2010, 95 (2010). Jakarta. Retrieved from 
http://www.batan.go.id/prod_hukum/extern/pp53.pd f

7. Rahimi, M., \& Karkami, F. H. (2015). The role of teachers' classroom discipline in their teaching effectiveness and students' language learning motivation and achievement: A path method. Iranian Journal of Language Teaching Research, 3(1), 57-82. Retrieved from www.urmia.ac.ir/ijltr

8. Rahman, A. (2014). Peningkatan disiplin kerja guru di sekolah dasar yayasan mutiara gambut. Jurnal Administrasi Pendidikan, 2, 1-9. Retrieved from http://ejournal.unp.ac.id/index.php/bahana/article/vi ew/3695/2932

9. Shih, C.-L., Wu, C.-C., Lai, F.-P., \& Liao, C.-W. (2015). The Study of Teachers' Attitudes of Positive Disciplines and Class Management Effectiveness in Junior High School. International Journal of Information and Education Technology, 5(7), 507511. https://doi.org/10.7763/IJIET.2015.V5.558

10. Stanley, E. O. (2014). Discipline and Academic Performance (A Study of Selected secondary Schools in Lagos, Nigeria). International Journal of Academic Research in Progressive Education and Development, 3(1), 181-194. https://doi.org/10.6007/IJARPED/v3-i1/758

11. Sugiyono. (2016). Statistika untuk Penelitian. Bandung: Alfabeta

12. Sukmadinata, NS. (2013). Metode Penelitian Pendidikan. Bandung: Rosdakarya

13. Susanty, A., \& Baskoro, S. W. (2012). Pengaruh Motivasi Kerja dan Gaya Kepemimpinan Terhadap Disiplin Kerja Serta Dampaknya Pada Kinerja Karyawan (Studi Kasus Pada PT. PLN (Persero) APD Semarang). Jati UNDIP, 7(2), 77-84.

14. Undang-undang Nomor 20 Tahun 2003. (2012). Undang-Undang Republik Indonesia Nomor 20 Tahun 2003 Tentang Sistem Pendidikan Nasional. Uma Ética Para Quantos?, XXXIII(2), 81-87. https://doi.org/10.1007/s13398-014-0173-7.2

15. Walters, J., \& Frei, S. (2007). Managing Classroom Behavior and Discipline. Oceanus.

16. Wuryandani, W., Maftuh, B., \& Budimansyah, D. (2014). Pendidikan Karakter Disiplin Sekolah Dasar. Cakrawala Pendidikan, 33(2), 286-295. Retrieved from https://journal.uny.ac.id/index.php/cp/article/view/2 168 